\title{
Vaccination influences growth of Arctic charr
}

\author{
Päivi Pylkköo ${ }^{1, *}$, Tapani Lyytikäinen ${ }^{2}$, Ossi Ritola ${ }^{3}$, Sinikka Pelkonen $^{1}$ \\ ${ }^{1}$ National Veterinary and Food Research Institute, Kuopio Regional Laboratory, PO Box 92, 70701 Kuopio, Finland \\ ${ }^{2}$ Finnish Game and Fisheries Research Institute, Evo Fisheries Research and Aquaculture, Rahtjärventie 291, 16970 Evo, Finland \\ ${ }^{3}$ Finnish Game and Fisheries Research Institute, Tervo Fisheries Research and Aquaculture, 72210 Tervo, Finland
}

\begin{abstract}
There is limited knowledge about the effects of oil-based vaccines on the growth of Arctic charr Salvelinus alpinus, in particular at different rearing temperatures. Oneyear-old Arctic charr were immunized intraperitoneally at $2.9^{\circ} \mathrm{C}$ with a metabolizable oil-adjuvanted, bivalent vaccine containing killed typical and atypical Aeromonas salmonicida bacteria. After vaccination the non-vaccinated (controls) and vaccinated individually marked fish were held for $20 \mathrm{~d}$ at $10.0^{\circ} \mathrm{C}$ and then for $7 \mathrm{wk}$ at $10.3,14.1$ or $18.1^{\circ} \mathrm{C}$. During the first $20 \mathrm{~d}$ at $10.0^{\circ} \mathrm{C}$ the growth rate $(G)$ was higher for non-vaccinated than vaccinated fish. Thereafter vaccinated charr had higher $G$ than control fish at 10.3 and $14.1^{\circ} \mathrm{C}$. In contrast, at $18.1^{\circ} \mathrm{C}$ there was no difference in $G$ and therefore no compensation of earlier growth suppression in vaccinated fish was observed at that temperature. The study indicates that vaccination has no ultimate negative effects on the growth of Arctic charr at temperatures ranging from 10.3 to $14.1^{\circ} \mathrm{C}$.
\end{abstract}

KEY WORDS: Vaccination · Growth $\cdot$ Temperature $\cdot$ Arctic charr

Resale or republication not permitted without written consent of the publisher

Vaccination against furunculosis and vibriosis is well-established in fish culture. Intraperitoneal (i.p.) vaccination with oil-adjuvanted vaccines has been reported to result in either enhanced (Buchmann et al. 1997) or reduced fish growth (Lillehaug 1991, Lillehaug et al. 1992, Midtlyng 1997, Midtlyng \& Lillehaug 1998). Knowledge about the effects of oil-based vaccination on growth of Arctic charr Salvelinus alpinus is limited. The temperature in which fish are cultured after vaccination may influence the effects of the vaccine. The optimum temperature for growth of Lake Inari Arctic charr has been reported to range from 10 to $14^{\circ} \mathrm{C}$ (Lyytikäinen et al. 1997). We chose to study how

*Present address: Finnish Game and Fisheries Research Institute, Laukaa Fisheries Research and Aquaculture, Vilppulantie 415, 41360 Valkola, Finland.

E-mail: paivi.pylkko@rktl.fi i.p. vaccination with an oil-based vaccine influences growth of Arctic charr at 3 temperatures: 10.3, 14.1 and $18.1^{\circ} \mathrm{C}$.

Materials and methods. On April 26, 1996 (Day 0), a group of Arctic charr (average weight $=25.2 \mathrm{~g}, \mathrm{SD}=$ $7.6 \mathrm{~g})$ was i.p. vaccinated at $2.9^{\circ} \mathrm{C}\left(0.2 \mathrm{ml} \mathrm{fish}{ }^{-1}\right)$ with an oil-based, bivalent vaccine containing killed Aeromonas salmonicida subsp. salmonicida and atypical $A$. salmonicida bacteria (Alpharma Inc., Norway) (Fig. 1). A group of non-vaccinated fish served as controls, marked by clipping the adipose fin. Charr were kept in $4 \mathrm{~m}^{2}$ tanks at ambient water temperature and fed at a low ratio $\left(<0.5 \%\right.$ of body weight $\left.\mathrm{d}^{-1}\right)$.

Fish were individually marked i.p. $25 \mathrm{~d}$ after the vaccination with passive integrated transponder (PIT) tags under tricaine sulphonate, MS-222 $\left(0.15 \mathrm{~g} \mathrm{l}^{-1}\right)$, anaesthetisation, to allow individual growth measurement. Water temperature was $6^{\circ} \mathrm{C}$ at the time of tagging. Fish were then held in $4 \mathrm{~m}^{2}$ tanks for $7 \mathrm{~d}$, until the start of experiment, and fed as before (Fig. 1).

The fish were distributed amongst 9 fiberglass tanks $32 \mathrm{~d}$ after the vaccination (72 vaccinated/31 control fish per $250 \mathrm{ltank}$ ) and kept for $20 \mathrm{~d}$ at $10.0^{\circ} \mathrm{C}$. Fish were fed in excess by belt feeders $\left(8 \mathrm{~h} \mathrm{~d}^{-1}\right.$, from 04:00 to $12: 00 \mathrm{~h}$ ) with commercial salmon feed (Tess Nutra G, $3.0 \mathrm{~mm}: 47.6 \%$ protein, $21.1 \%$ lipid, $8.8 \%$ water; energy content $21.1 \mathrm{~kJ} \mathrm{~g}^{-1}$ ) and kept under a photoperiod of $16 \mathrm{~h}$ light:8 $\mathrm{h}$ dark during the experiment. Then temperature was changed within $8 \mathrm{~h}$, to either 14.1 or $18.1^{\circ} \mathrm{C}$, or kept at $10.3^{\circ} \mathrm{C}$ ( 3 tanks per temperature). These temperatures were maintained for $7 \mathrm{wk}$. Fish were weighed on Days 32, 49, 75 and 103. Growth rates $(G)$ of the individuals within the tanks were calculated over 3 periods (first: Days 32-49; second: Days $50-75$; third: Days 76-103) as: $G=\left[\left(\ln W_{1}-\ln W_{0}\right)\right] /\left(t_{1}-\right.$ $t_{0}$ ), where $W_{1}=$ weight at the end of a period $(\mathrm{g}), W_{0}=$ weight at the start of a period $(\mathrm{g})$ and $t_{1}-t_{0}=$ length of the period in days. 


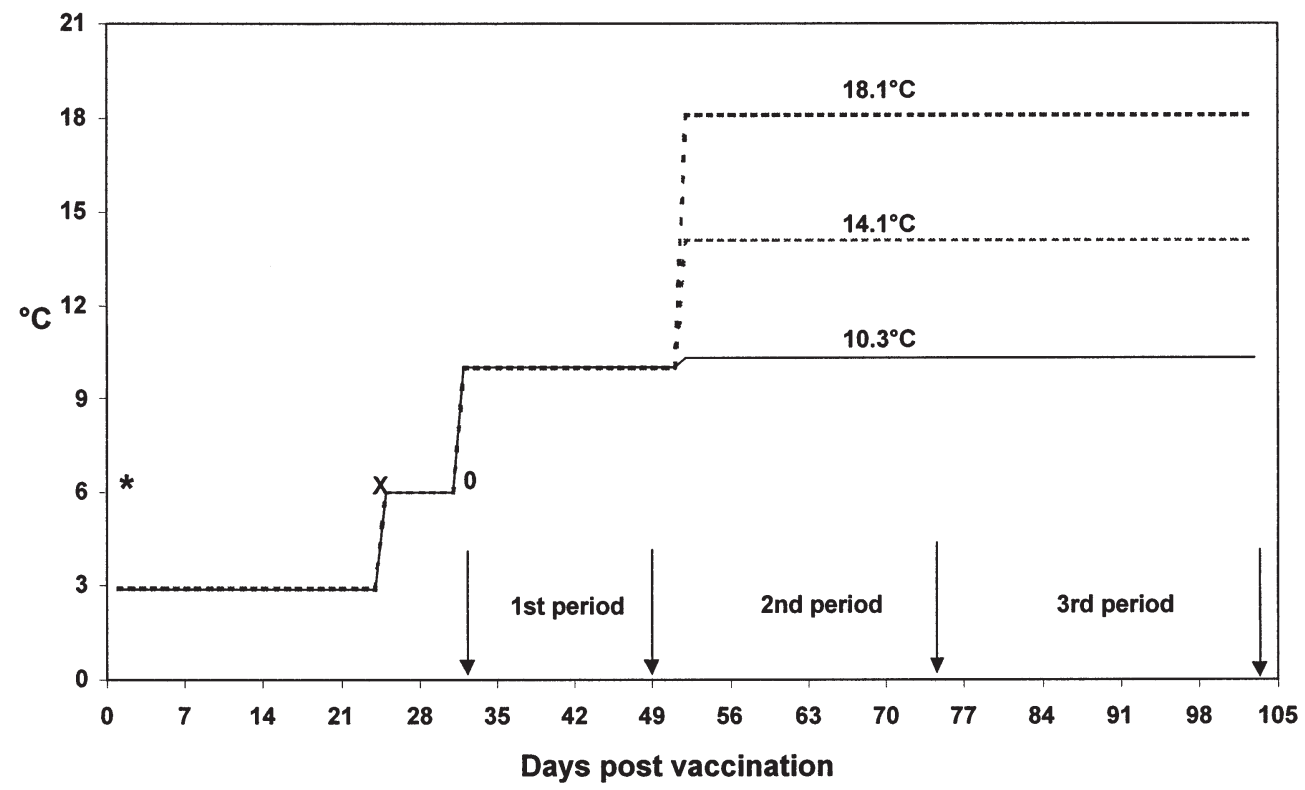

Fig. 1. Experimental design. One-year-old Arctic charr Salvelinus alpinus (average $=25.2 \mathrm{~g}, \mathrm{SD}=$ $7.6 \mathrm{~g})$ were intraperitoneally vaccinated on April 26, 1996 (*). The fish were individually tagged (x). Vaccinated and non-vaccinated charr were placed into 3 temperature treatment groups (72 vaccinated/31 control fish per $250 \mathrm{l}$ tank; 3 replicates in each temperature; total of 9 tanks) (0). Weighing of individuals ( $\downarrow$ ) was performed 4 times

The influence of vaccination on $G$ was tested according to a nested-factorial design (Montgomery 1997). In the model the effect of temperature was nested with tanks and vaccination was a factorial factor (Montgomery 1997). Within a temperature treatment group the influence of vaccination was tested by simple contrasts (SYSTAT 1997).

Results and discussion. There were no weight differences between the parallel groups (pooled average = $25.5 \mathrm{~g}, \mathrm{SD}=7.6 \mathrm{~g}$ ) at the time of distribution of fish into the tanks (Day 32). In the first period (Days 32-49, at $10.0^{\circ} \mathrm{C}$ ), the control charr had higher $G$ than the vaccinated fish. The difference in growth between vaccinated and control fish was similar in all the tanks at that time (Fig. 2).

After the 3 temperature treatments were established (Day 52) the vaccinated fish grew faster than the controls at 10.3 and $14.1^{\circ} \mathrm{C}$ (second and third periods) (Fig. 2). However, at the same time there was no significant differences in $G$ between the vaccinated and the control fish kept at $18.1^{\circ} \mathrm{C}$ (Fig. 2). As a result there was no significant difference in weight between the vaccinated and the control fish at 10.3 or $14.1^{\circ} \mathrm{C}$ at the end of the experiment, but the vaccinated fish held at $18.1^{\circ} \mathrm{C}$ had a lower body weight than the controls (Table 1). Thus the vaccinated charr were able to compensate for reduced growth at temperatures close to the optimum growth temperature range (10.3 to $14.1^{\circ} \mathrm{C}$ ) but not at a temperature above it.

In charr kept at 10.0 and $10.3^{\circ} \mathrm{C}$ from Day 32 to Day 103 after vaccination, we could analyze how $G$ changed over time. Growth suppression was observed in vaccinated Arctic charr in the first period (Days 32 to 49). Our result for Arctic charr is not consistent with the results of Midtlyng et al. (1996), who reported that reduced appetite or growth could no longer be observed 3 wk after i.p. vaccination in Atlantic salmon Salmo salar. Impaired growth and the duration of growth suppression after vaccination may be related to activation of the immune system in vaccinated fish (Poppe \& Breck 1997) or result from lesions at the injection site (Midtlyng et al. 1996) and may vary among different species.

The results indicate that the side effects of vaccination on Arctic charr are influenced by water temperature. The temperature at which studies are performed plays an important role in data analysis, because temperature may allow compensatory growth or prevent it. This is reflected in the relationship between the duration and the results of the study. For instance, our results for the final weight of Arctic charr (Table 1) are consistent with the results of Midtlyng \& Lillehaug (1998), who observed a negligible or negative effect of vaccination on growth of Baltic salmon. This consistency requires that we do not take into account the variation of $G$ over time: the growth of vaccinated Arc-

Table 1. Weight $(\mathrm{g})$ of intraperitoneally vaccinated Arctic charr Salvelinus alpinus at 3 experimental temperatures $103 \mathrm{~d}$ after vaccination. The number of fish is given in the legend of Fig. 2. ${ }^{* * *} \mathrm{p}<0.001$

\begin{tabular}{|lrr|}
\hline \multirow{2}{*}{$\begin{array}{l}\text { Temperature } \\
\left({ }^{\circ} \mathrm{C}\right)\end{array}$} & \multicolumn{2}{c|}{ Mean weight \pm SE $(g)$} \\
& Non-vaccinated charr & Vaccinated charr \\
\hline 10.3 & $70.1 \pm 2.2$ & $71.8 \pm 1.8$ \\
14.1 & $75.3 \pm 3.3$ & $76.7 \pm 2.1$ \\
18.1 & $64.1 \pm 4.3$ & $49.6^{* * *} \pm 1.6$ \\
\hline
\end{tabular}





Fig. 2. Influence of vaccination on growth rates $(G)$ of Arctic charr held under 3 temperature regimes. Values are given as means \pm SE. Non-vaccinated groups $\left(\mathrm{n}=56,50\right.$ and 46 at $10.3,14.1$ and $18.1^{\circ} \mathrm{C}$, respectively) are indicated by open columns and vaccinated groups $\left(\mathrm{n}=137,127\right.$ and 108 at $10.3,14.1$ and $18.1^{\circ} \mathrm{C}$, respectively) by filled columns. ${ }^{* * *} \mathrm{p}<0.001,{ }^{* *} \mathrm{p}<0.01, \mathrm{NS}=\mathrm{p}>$ 0.05. Temperature treatments are indicated and dotted vertical line indicates the time of temperature change

tic charr was significantly higher at the end of experiment at $10.3-14.1^{\circ} \mathrm{C}$. If we would have performed a longer experiment with Arctic charr at 10.3 and $14.1^{\circ} \mathrm{C}$, we may have gained results in agreement with the results of Buchmann et al. (1997) on Atlantic salmon. They observed higher weight gain for vaccinated Atlantic salmon. In contrast, in a shorter experiment we would have observed only the growth suppression caused by vaccination. It can be concluded that the effect of vaccination on Arctic charr growth may last over $3 \mathrm{mo}$, and therefore, the studies of the side effects of vaccination on Arctic charr should last preferably longer. However, our observations on Arctic charr do not offer an explanation for the contradictory results about side effects of vaccination, since vaccination procedures, rearing conditions and fish species vary between studies.

Compensation of growth suppression was not seen in vaccinated fish during the time of the experiment at $18.1^{\circ} \mathrm{C}$. However, growth suppression was compensated at 10.3 and $14.1^{\circ} \mathrm{C}$. This indicates that vaccination with modern oil-adjuvanted vaccines has no ultimate negative effect on growth of Arctic charr at temperatures below their optimum growth temperature $\left(14^{\circ} \mathrm{C}\right)$ or in conditions where compensatory growth can be performed by Arctic charr. 
Acknowledgements. The experiment was funded by the Finnish Ministry of Agriculture and Forestry, Finnish Game and Fisheries Research Institute, Graduate School of Fisheries and Fish Biology in Finland and the Nordic Council project 66080400 . We also appreciate the valuable comments of Drs Malcolm Jobling, Christian Syvertsen, Kari Ruohonen and Tellervo Valtonen.

\section{LITERATURE CITED}

Buchmann K, Dalsgaard I, Nielsen ME, Pedersen K, Uldal A, Garcia JA, Larsen JL (1997) Vaccination improves survival of Baltic salmon (Salmo salar) smolts in delayed release sea ranching (net-pen period). Aquaculture 156:339-351

Lillehaug A (1991) Vaccination of Atlantic salmon (Salmo salar L.) against cold-water vibriosis - duration of protection and effect on growth rate. Aquaculture 92:99-107

Lillehaug A, Lunder T, Poppe TT (1992) Field testing of adjuvanted furunculosis vaccines in Atlantic salmon, Salmo salar L. J Fish Dis 15:485-496

Editorial responsibility: Carl Schreck, Corvallis, Oregon, USA
Lyytikäinen T, Koskela J, Rissanen I (1997) The influence of temperature on growth and proximate body composition of underyearling Arctic charr. J Appl Ichthyol 13:191-194

Midtlyng PJ (1997) Vaccinated fish welfare: protection versus side-effects. In: Gudding R, Lillehaug A, Midtlyng PJ, Brown F (eds) Fish vaccinology. Dev Biol Stand 90. Mediciné et Hygiené, Basel, p 371-379

Midtlyng PJ, Lillehaug A (1998) Growth of Atlantic salmon Salmo salar after intraperitoneal administration of vaccines containing adjuvant. Dis Aquat Org 32:91-97

Midtlyng PJ, Reitan LJ, Speilberg L (1996) Experimental studies of the efficacy and side-effects of intra-peritoneal vaccination of Atlantic salmon (Salmo salar L.) against furunculosis. Fish Shellfish Immunol 6:335-350

Montgomery DC (1997) Design and analysis of experiments, 4th edn. John Wiley \& Sons, New York, p 519-521

Poppe TT, Breck O (1997) Pathology of Atlantic salmon Salmo salar intraperitoneally immunized with oil-adjuvanted vaccine. A case report. Dis Aquat Org 29:219-226

SYSTAT (1997) SYSTAT ${ }^{\circledR} 7.0$ for Windows: statistics. SPSS Inc, Chicago

Submitted: September 15, 1998; Accepted: June 19, 2000

Proofs received from author(s): September 28, 2000 